\title{
Music in Jean-Paul Sartre's Philosophy
}

\author{
Martina Stratilková
}

Jean-Paul Sartre (1905-1980) was an outstanding writer and an existentialist-oriented phenomenologist, who was close to the arts and also expressed his opinions on this subject. Among his philosophical publications, the early works in particular are relevant to music, and besides, we can find direct reference to music or we can presume likewise if we consider the significance of themes like the feeling ${ }^{1}$ or the function of consciousness in formation of ideas. ${ }^{2}$ In this context, we will try to outline the nature and development of Sartre's views of music and its meaning, whereas we will start from his work L'Imaginaire, where Sartre suggested his own concept of imagination after he had introduced a critique of various concepts of imagination in his book L'Imagination in 1936.

Sartre viewed the nature of imagination (imaging consciousness) particularly through its distinction from perception (perceptive consciousness). He presumes that perceptive and imaging consciousness are different states, whereas one excludes another, and "the image as image is describable only by a second-order act", ${ }^{3}$ it is a reflection of the perceived object. Sartre makes further determination of imagination. Essential poverty of the image results from its origin in consciousness and not in the world. What appears in perception and in imagination, although the original object could be the same, is processed in a different way or with different intentionality in consciousness: "Only, in one of the cases, the chair is 'encountered' by consciousness; in the other, it is not." ${ }^{4}$ If I perceive an object, it stands in front of me, but if I imagine the object, I must bring it to presence, call it into consciousness, because the object itself is otherwise not present in the consciousness. And non-presence of the object means that the consciousness posits

1 Jean-Paul Sartre, Esquisse d'une théorie des émotions (Paris, 1939). Here as Sketch for a Theory of the Emotions (London - New York, 2002).

2 Jean-Paul Sartre, L'Imaginaire (Paris, 1940). Here as The Imaginary (London - New York, 2004).

3 Jean-Paul Sartre, The Imaginary (London - New York, 2004).

$4 \quad$ Ibid., p. 7. 
its object as a nothingness (the object does not exist, it is not anywhere, it is somewhere else, it is neutralised in its existence).

If consciousness is not tied to the form of the object, by which it is fully given to the senses, its own activity becomes more independent. Thus Sartre places passivity of perception in contrast to spontaneity of imagination and stresses that image is not a thing but an act. Perception is clogged with abundance of perceived aspects, through which the thing is appearing, as it conforms to Husserl's theory of adumbration, and therefore it is constituted gradually and it principally remains unfinished. But imagination, as a spontaneous act, does not constitute its object with such necessity, which is peculiar to perception. Imagination, which has not been awakened by some external object, is invoked by an internal cause and cannot add anything to the object (it is therefore essentially poor). Objects emancipate from the boundaries of binding constitution, because "the imagined objects are seen from several sides at once". ${ }^{5}$ Imagined objects do not fulfil abundance of aspects, through which the object manifests in consciousness, nor do they choose any of the positions, from which the object was viewed. Instead, they "are "presentified' under a totalitarian aspect". ${ }^{6}$ Although Sartre adds that also in the imagination the objects present themselves in a specific position, such manifestation is only accidental and it dissolves, respectively "gathers" particular positions of the elements of the object into "invariable synthesis".

Applying this postulate of so-called immanent consciousness (with intention focused on the act of relation to the object) to the whole sphere of the Arts is rather daring as it does not distinguish an aesthetic object from a work of art and therefore does not presume (in Ingarden's words) concretisation of the work, even though it places the work in contrast to a real object (analogon). But analogon represents rather an inanimate substrate, for example "work-thing” in Jan Mukařovský's terminology. Image could also be regarded as a sign gifted by a reference originating outside itself. But Sartre is more careful. In his opinion, the image is "symbolic in essence and in its very structure" ${ }^{8}$ It functions mainly on the basis of similarity and therefore it is a natural sign. The conveyed meaning can be envisaged as understanding, which is uncompleted. B contrary signification using conventional stable-based expressions stands out as "simple intuition of a naked thought".

The recipient of the work of art is thus confronted with meanings that are, in a certain sense, nontransparent and that is also why Sartre claims that through imagination we enter the sphere of magic: "The act of imagination, ..., is a magical act. It is an incantation destined to make the object of one's thought, the thing one desires, appear in such a way, that one can take possession of it. There is always in that act, something of the

\footnotetext{
Ibid., p. 125.

6 Ibid.

7 Ibid., p. 130.

$8 \quad$ Ibid., p. 98.

$9 \quad$ Ibid., p. 116.
} 
imperious and the infantile, a refusal to take account of distance and difficulties." ${ }^{10}$ In imagination we adjust the world according to our own perception; the intended object loses its stimulating power, which can be tenacious. So, imagination is "an escape from all the constraints of the World", "a negation of the condition of being in the world", "an anti-world". ${ }^{11}$ The world, or better said, the irrealized world, presents objects and situations according to a known schedule - how else, when imaging consciousness does not wait for the configuration of outer conditions, but constitutes the world from its own sources, created on the basis of previous perceptions. The way in which the world is experienced is more or less under the control of consciousness, Sartre can say about the imagined objects: "Only the 'essential poverty' of objects as imaged can satisfy the feeling docilely, without ever surprising it, deceiving it or guiding it." 12

In comparison with sensual objects, imagined objects, which are "quasi-sensible things", ${ }^{13}$ are more attractive due to simple presentation of the object, although it is at the same time depleting if compared to the perception: "None of its qualities are pushed to the limit." ${ }^{14}$ The object loses its fully depicted individualized form and becomes ambiguous. Since it is absolutised as an imagined object in the sense that it includes all possible positions as a whole and in unity, it loses relation to its environment, bears its own time and space and is self-contained. Therefore we cannot speak of an imaginary world; if the imagined objects break their mutual bonds, they have no horizon.

At this point we could start a significant discussion about the connection between imagination and art. Because Sartre himself mentions this connection, it is clear that he regards art as one of the domains of imagination. Sartre sees art objects as images that are revealed through a sensory accessible analogon. If Sartre thinks of the relation between the image and the depicted object as of inner relation, resulting from the character of the material, then it is odd that he specifies this inner relation as resemblance applicable, apart from other things, to all Arts. ${ }^{15}$ What do tones relate to on the base of this resemblance? In music, we can identify some parameters, for example that of movement or intensity, and link these quantitative characteristics to different spheres of extra-musical reality; however, these spheres can hardly be specified by the music structure itself. At first, Sartre doubts if music relates to anything irreal and he is satisfied with the evidence of our awareness of the fact that the musical work is not identical to the sounds bearing the work. Music thus also constitutes an irreal object. Sartre does not specify the nature of musical image, he just points out the conditions of its constitution (out of the real time and space; with a feeling of being given personally, although it is not present). But Sartre

\footnotetext{
Ibid., p. 125.

Ibid., p. 136.

Ibid., p. 147.

3 Ibid., p. 125.

$14 \quad$ Ibid., p. 133.

15 Cf. ibid., p. 188-194.
} 
himself says: "A melody, for example, refers to nothing but itself." ${ }^{16}$ It is therefore hard to view music as an analogon through which an image appears. Sartre is inconsistent in determining when a real object refers to something by its own structure and on the base of resemblance with the represented object, and he is also inconsistent on the other side: he speaks of an analogon in the case of literature, which however refers (almost entirely) on the basis of signs, that have conventionally stabilised meanings. If Sartre sets against each other a "sign" and an "image" according to the form of representation - resemblance or convention - what does the term "verbal analogon" (resp. "verbal analogons" ${ }^{17}$ ) mean?

Let's return to the imaginative nature of works of art and music. According to Sartre, the imaginary cannot constitute the whole world, only particular images that are independent of one another and disconnected. But works of art are formations with a strong inner structure, they are composed of parts, which somehow connect to one another and also imply some kind of sequence, which the consciousness should respect to be able to understand the work of art through the sensory data. They therefore represent a certain world, which has its rules. Maybe it would be exaggerating to mention musical writers of the $19^{\text {th }}$ century, who appreciated the beautiful world created by music, which is so different to our ordinary world. But it seems that in the world of arts, the price we have to pay for the gift of unreality (essential poverty), which enables us to consider things in the imaginative attitude, is rather low; on the contrary the fragmental and indistinct form of imaginary objects, which usually takes away their beauty, is overcome here.

And music in particular does really well among other arts. This idea cannot be found in Sartre's work, but we can mention phenomenologist aesthetician Mikel Dufrenne ${ }^{18}$, who was significantly inspired by Sartre in some points. Dufrenne stressed that aesthetic objects of works of art connect impermeable sensuality with spiritual meaning, imprinted into physical material. This leap in meaning endows the sensory matter with inwardness, which is why Dufrenne denoted an aesthetic object as a quasi-subject and pointed out that music in particular is able to detach an aesthetic object from its surroundings and penetrate into its depth. In his opinion, music has no meaning outside its own world (as formalistic oriented aestheticians would eagerly agree).

Sartre applied his theory of imagination to a group of artforms rather indistinguishably and, although he dealt with polarity of the physical bearer and unfolding meaning in a similar way to other authors of phenomenological works on music (Conrad, Ingarden), his work on imagination is an interesting contribution especially to the issue of experiencing an artwork. Here Sartre arrives at the existentialistic conclusion that a man is endowed with freedom of consciousness, which ultimately distances him from the world. And the very imaginative acts express the freedom of consciousness - they are endowed with high spontaneity. Sartre presumes that to be able to posit the world, we must be able to stand back from it (for example through imaginative acts), by which means we deny or "negate"

$16 \quad$ Ibid., p. 191.

17 Ibid., p. 191.

18 Mikel Dufrenne, Phenomenology of Aesthetic Experience (Evanston, 1973). 
the world. But imaginative acts represent rather a training of such move, because escape from the world happens in close sequence to perception, which remains overpowered by reality. In addition, we can agree with Eugen Kaelin, ${ }^{19}$ who claims that non-figural artistic objects can hardly be viewed as images, able to depict another object through their resemblance. But this is different in the case of irrealizing function, on which some of Sartre's interesting observations on the acts of consciousness are based and which is therefore relevant for conceiving aesthetic experience.

At the time when Sartre worked on his imagination theory, he also wrote his work Esquisse d'une théorie des émotions. Here we can find a range of similar thoughts as in the book L'Imaginaire, written only a short time later. Similarly as in the case of imagination, Sartre stresses that emotions represent mainly a certain attitude, certain meaning appointed to objects and our way of comprehension. Much like the imaginary, emotion also enables us to escape the constraints and worries of the real world, but especially its reality and actuality. Emotion is according to Sartre "transformation of the wold" ${ }^{20}$, which has become unbearable: "All ways out being barred, the consciousness leaps into the magical world of emotion, plunges wholly into it by debasing itself." ${ }^{21}$ The consciousness loses its "point of view upon the world" and "an obscuration of the conscious point of view upon the world" 22 is approaching instead. The consciousness leaves the area where it takes views and changes to living in direct behaviour. It surrenders to the magic of the object as if it was falling asleep, it loses power over itself : "It does not dominate the belief that it is doing its utmost to live, and this precisely because it is living that belief and is absorbed in living it." ${ }^{23}$ Also in L'Imaginaire Sartre says: "Aesthetic contemplation is an induced dream and the passage to the real is an authentic awakening." ${ }^{24}$ The outer world appears to be unfavourable and as such it is unacceptable for the consciousness; we can try to change it or to do something about it. But the repertoire of common attitude might not always be sufficient. Then comes the magic quality of emotion, which "attributes to the object something that infinitely transcends it". ${ }^{25}$ But emotion cannot change the world. It can only influence assigning of significance: it can proceed to the "change of intention", ${ }^{26}$ which can "annihilate" the world. If we cannot change the world, we must at least try to change its perception, assign it a "lesser existence or a lesser presence" ${ }^{27}$ Emotion will then change the consciousness itself and its fundamental approach - it will deny it, bring

\footnotetext{
19 Eugene Kaelin, An Existentialist Aesthetic (Madison, 1962), p. 83-86. 
it to nothingness, remove it. The consciousness will deny itself and only secondarily and indirectly will it deny the inconvenient world.

If we seek some parallel to Sartre's work on the imaginary on a general level, we can claim that the magic quality of emotion resonates with the magic quality of imaging consciousness in the intentionality which is absolute and not adumbrating. We have defined the difference between imagination and perception based on, among other things, the following: while perception handles an object in many aspects and in a process, which is basically endless, imagination calls the object into consciousness in a single act as if it concentrated all its aspects and moments into an integrated, although not very clear form. Sartre also ascribes emotions to "passing over to the infinite", because emotional experience represents "the units of an infinity of real and possible abschattungen". The consciousness for example handles the horror of a certain object "suddenly", whereas the horror appears to be "an overwhelming and definitive quality of the thing". ${ }^{28}$

$\mathrm{We}$, of course, associate music with high values and levels of emotional sensation. And although it is often repeatedly pointed out that emotions awakened through listening to music are not specific towards the music structure, there is a considerable consent over the presumption that we must understand the musical structure, we must come to an understanding. ${ }^{29}$ Such understanding does not strictly constitute rational quality, considering the non-discursive nature of music, but it should be regarded as an overall understanding, that is experiencing the meaning, which includes an experience component. The idea of conceiving emotions in close relation to understanding music therefore does not lose justness, besides according to Sartre, emotion is defined by its meaning, appointed to an object: "Emotion is a specific manner of apprehending the world." 30

With the view of musical artistic context, Sartre's distinction of the two forms of emotion is very important. On one hand there is a subjective constitution of a magic world, (we have watched the emotion's character in this example), and on the other hand there is the magic of the world itself. Magic is also connected with things "inasmuch as they may present themselves as human ... or bear the imprint of the psychic". ${ }^{31}$ The second meaning in particular, magic dwelling in the world itself, offers an opportunity to view musical manifestations, because they belong to highly spirited objects, already by the intention to create them and by placing them into a context, from which the spirituality is expected. We must also note that Sartre set apart refined emotions, which he characterizes as "slight oscillation of our physical condition" 32 and which deal with the objective quality of the object. In such case, the emotion itself can be deep in its meaning, important and strong,

28 All ibid., p. 54.

29

Cf. Otakar Zich, "Hodnocení estetické a umělecké” [Aesthetic and Artistic Evaluation], Česká mysl [Czech Mind], 16 (1917), Vol. 3-4, p. 129-165. Zich discusses intuitive understanding of a work of art.

30 Jean-Paul Sartre, Sketch for a Theory of the Emotions (London - New York, 2002), p. 35.

$31 \quad$ Ibid., p. 58.

32 Ibid., p. 55. 
but the consciousness has not yet been affected to such point as to be able to change the world completely; the change is only implied. While strong emotions strike the body, the bodily accompaniment of refined emotions is only moderate. Aesthetic condition can also be specified by a shift of consciousness in the sense of giving oneself up to the object. Moritz Geiger for example mentions forgetting oneself when encountering a work of art ("Selbstvergessenheit" ${ }^{33}$ ), Mikel Dufrenne speaks of self-alienation: "alienation of the subject in the object" ${ }^{34}$. Although Sartre uses a rather pejorative language ${ }^{35}$, when referring to degradation of consciousness, his conception of falling for the aura of the object with consequences for the self-consciousness is analogical.

Sartre's definition of the transition to the magic world, which could be compared to the transition to the aesthetic attitude, also deserves our attention. Under normal circumstances, the consciousness remains in the world, which appears to be a complex of resources. In the case of an extraordinary situation, the consciousness analyses the situation and its various parameters and subsequently takes corrective measures by effecting on specific moments of the situation. Transition to the magic world represents a fundamental change of attitude, which copes with emotional flooding of situations when the world affects the consciousness imminently, "at no distance and without means" ${ }^{36}$ The change in the world itself offers resemblance to the aesthetic attitude as under such conditions we give up the world of resources and at the same time we don't need to feel the emotion through our bodily behaviour, which is given by the fact that "the emotion has no finality". ${ }^{37}$ Sartre, for example, spoke about situations of sudden fright or admiration about absorption in the experienced object. These situations contain a high stimulating value of the object, which causes invasion of the emotional world, emotional flooding and a kind of desinterestedness.

Both mentioned early works of Sartre are truly very close not only considering the time of their creation, but also regarding the presented opinions. Further detailed specification of Sartre's work on emotions for the field of music would have to be suggested. In the first half of the $20^{\text {th }}$ century (in consequence to formalistic aesthetics), we can find numerous contributions in which their authors distinguished among ways of aesthetic perception of music, while the adequacy of the perception emerging correlatively to the musical structure became an important device. Some of these aestheticians or theorists see music as an art form, which is more open to emotionality and which is, due to this

33 Moritz Geiger, "Beiträge zur Phänomenologie des ästhetischen Genusses”, Jahrbuch für Philosophie und phänomenologische Forschung, 1 (1913), p. 567-684, here p. 652.

34 Mikel Dufrenne, Phenomenology of Aesthetic Experience (Evanston, 1973), p. 56.

35 Consciousness should be able to realise a free positing of the world. This presumes the possibility to step out of the world, to posit it as a whole. And in the case of a situation that cannot be controlled by the consciousness, as when flooded with emotions, such condition is very unlikely.

36 Jean-Paul Sartre, Sketch for a Theory of the Emotions (London - New York, 2002), p. 60.

37 Ibid., p. 55. 
primacy, perceived emotionally to the prejudice of artistic message. ${ }^{38}$ So music could be a sphere, probably together with literature, which easily and strongly evokes the magic world of emotions.

In Sartre's aforementioned early works, preliminary to his main philosophical treatise L'Être et le néant, we encounter a coherent explanation of the structures of consciousness, which free the consciousness by rising from the world, which up to now seemed to be significant. Also, artistic objects can participate in such rising, especially music, which embodies significant potency of the imaginative world and strong emotional magic. A few years later Sartre wrote about literature: Qu'est-ce que la littérature?, ${ }^{39}$ and he tried to define its communicative potential in contrast to other kinds of art. In this work we can identify just a very general connection to Sartre's general philosophical issues, but the importance of this work rises especially due to relation to music. Not because of its specificity but because of the conceptuality that is relevant especially in art. Comments on music are expressed as part of an argument, comparing poetry, painting and music on one side - art - and literature on the other side.

Sartre mainly deals with relationship between poetry and prose, which is amplified by conceiving poetry in a similar way as music or painting. Only literature can refer to some other reality: "The art of prose is employed in discourse; its substance is by nature significative; that is, the words are first of all not objects but designations for objects [...]." ${ }^{40}$ The sign is transparent; it lets the intention pass through it to the meaning. The artist stops by the very sensory quality and is charmed by it. He cannot step over the sensory material: "And it is one thing to work with colour and sound, and another to express oneself by means of words. Notes, colours, and forms are not signs. They refer to nothing exterior to themselves." ${ }^{41}$ Sartre proceeds to a clear polarity, although it is strange that such a visual type of art as the fine arts does not admit reference. Sartre clearly associates the reference as bound to its verbal meaning and posits it against signs, while denoting is based on the character of the sign itself according to the semantic theory. He himself clarifies that sensory bound arts have no "definable significance" and do not "refer particularly to another object". ${ }^{42}$ As if in the case of this specifically structured thesis Sartre was afraid to say plainly what he otherwise keeps repeating in the text - that music or fine arts simply have no meaning. The truth is that he sometimes denies himself: "One does not

38 Moritz Geiger, "Beiträge zur Phänomenologie des ästhetischen Genusses”, Jahrbuch für Philosophie und phänomenologische Forschung, 1 (1913), p. 567-684; Herbert Eimert, "Zur Phänomenologie der Musik”, Melos, 5 (1926), Vol. 7, p. 238-245; Roman Ingarden, O poznawaniu dzieła literackiego [The Cognition of the Literary Work of Art] (Lwów, 1937); Otakar Zich, "Hodnocení estetické a umělecké”, Česká mysl, 16 (1917), Vol. 3-4, p. 129-165.

Qu'est-ce que la littérature? Published as a serial in 1947 in the magazine Les Temps Modernes. Here: Jean-Paul Sartre, What is literature? (London, 1993).

40

Ibid., p. 11.

${ }^{41} \quad$ Ibid., p. 1.

42 Ibid., p. 2. 
paint meanings; one does not put them to music.“ „On the other hand, the writer deals with meanings." ${ }^{43}$ On the other hand, music uses only such sensory qualities that do not refer the receiver anywhere else; it is therefore not transparency but the thing itself and the thing is impenetrable. A literature writer can illustrate emotion, but there is no such possibility in the poet's repertoire. Although the poet puts his emotions into a poem, he does it in such manner that they melt into a substance and cease to be emotions, because a physical object bears the "opacity of things". ${ }^{44}$

Therefore Sartre carefully claims that meanings cannot be defined in these artforms and they do not clearly refer to any reality. On the other hand he must directly admit a certain significance of the sensory material itself, when he says that colours have "something like a meaning" and defines his thought valid for music: "Doubtless the composition is also inhabited by a soul [...]." ${ }^{45}$ Nevertheless, we must acknowledge the difference between the inability of reference and a reference that cannot be set to words. Sartre privileges the strictly limited language meaning to such an extent that beyond its sphere he ceases to differentiate or he oscillates between acknowledging some meaning overleaping physical media and negating this possibility: "Similarly, the significance of melody - if one still can speak of significance - is nothing outside the melody itself, unlike ideas, which can be adequately rendered in several ways. Call it joyous or sad." ${ }^{46}$ It is surely possible to claim that meaning represents the quality that the recipient experiences when he perceives the work of art and which, in the case of music, is created by some processing of the sensory ground (at least as a "form" - organisation of the sound substance), by some meaning subtraction. Yet still, if Sartre wants to acknowledge some meaning and at the same time refrain from speaking about the meaning, he speaks about magic: "The words-things are grouped by magical associations of fitness and incongruity, like colours and sounds." ${ }^{47}$ Artistic manifestation therefore evokes certain magic, awakens something that outgrows it, something magic. But in the case of imagination and emotions this difference carried above all some kind of intentionality vertigo, dazing timbre relative to the world, while in this context he expresses the presence of certain contentual moments, we may say, it is truly an emergency denotation.

Sartre then acknowledges that aesthetic value is tied to sensory moments, when he says for the main that the aesthetic value in literature loses its meaning: "Beauty is in this case only a gentle and imperceptible force. In a painting it shines forth at the very first sight; [...]." "In prose the aesthetic pleasure is pure only if it is thrown in into the bargain." ${ }^{48}$ Sensuality therefore carries aesthetic value, but it brings up the question of what would create artistic value, because it should be defined through certain non-sensory moments

\footnotetext{
${ }^{43} \quad$ Ibid., p. 4.

$44 \quad$ Ibid., p. 10.

$45 \quad$ Ibid., p. 2.

$46 \quad$ Ibid., p. 3.

$47 \quad$ Ibid., p. 8.

$48 \quad$ Ibid., p. 13.
} 
and definition of such moments in the form of magic associations does not create a particularly strong conceptual framework.

In his work of 1947, Sartre arrives at a theoretically more competent concept, which is not truly sensitive in several aspects. Right within the fundamental distinction between literature and poetry, he mentions relevant accents of poetry and prose, but he absolutises their differences, when he demotes the meaning of words in poetry to a vague sensory quality, which has the same significance as a tone in music. On the other hand he absolutely denies reference in music. We can still find a rudiment of a more sophisticated conception - expression. While well defined signs (in Peirce's semantic we would say symbols) refer to something not present in the material itself, expressive signs are more based on presentation. Mikel Dufrenne ${ }^{49}$ will later speak about conveying feelings through the sensory material itself, which induces a feeling of vivid presence of the object. Sartre comes close to this solution, when he denies that music has the ability to speak through conventional signs. Although he says that sensory material can be processed just by introducing the imaginary mode, by this he only means stepping out of the reality mode. In addition, Sartre did not prove that positing music in the context of images (refering through resemblance) would be appropriate in his work L'Imaginaire. Both sign and image act likewise on a general level of signification: intention of consciousness proceeds towards "a matter that it transforms" and its result is "an object aimed at that is not present". ${ }^{50}$ So transformation of the material intends some new object. When Sartre later confronts literature with other arts, he mentions their perception in relation to the imaginary, but all of a sudden, they do not convey anything, do not refer to anything, they are just their own presentations. ${ }^{51}$ Thomas R. Flynn ${ }^{52}$ hoped that the emphasized absence of potential to denote another object through the work of art could be conceived as a third strength of arts, along with expression and representation. It is a shame that he did not confront his opinions on Sartre with Dufrenne, who assigned a very important role to the concept of presence as a primary form of perception, which takes place on a pre-reflexive level, basically on the sensuality level. But perception cannot be left entirely behind the gates of consciousness; in further phases it therefore reaches up to expressive strength of the aesthetic object. Nevertheless, we can notice that in his work on literature, Sartre describes certain music as sadness or happiness - mood characteristics explainable mainly as expressivity.

\footnotetext{
Mikel Dufrenne, Phenomenology of Aesthetic Experience (Evanston, 1973), p. 335-344.

so Jean-Paul Sartre, The Imaginary (London - New York, 2004), p. 21.

${ }_{51}$ Catherine Rau sees direct continuality between L'Imaginaire and Qu'est-ce que la littérature?, but we cannot agree with her. Distinguishing between art forms according to conventional or natural sign is coherent, but Sartre comes to different consequences - in his later work, he radicalises the polarity and implicit classification of art is different in the mentioned works. Cf. Catherine Rau, "The Aesthetic Views of Jean-Paul Sartre", The Journal of Aesthetics and Art Criticism, 9 (1950), p. 139-147, here p. 146.

52 Thomas R. Flynn, "The Role of the Image in Sartre's Aesthetic", The Journal of Aesthetics and Art Criticism, 33 (1975), p. 431-442.
} 
In 1950 Sartre wrote his foreword to René Leibowitz's book L'Artiste et sa conscience. ${ }^{53}$ He responded to Leibowitz's vision of possible music involvement and also to a proclamation on involved music originating in the Eastern Bloc. Sartre directly mentions outcomes of the international congress of music composers and critics in Prague, but also the influential Soviet promoters of Ždanov and Stalin. At first, Sartre responds to a question based on his consideration of the possible communicative potential of music. But he specifies the communicative possibilities of music in closer detail. Signification is a procedure occurring when we can think of another object through a relatively transparent original object. Music cannot denote, but it has sense that never diverts from the object which it occupies. This sense is embodiment of reality in the object, which it transcends, but which is not imaginable outside the object and because of its endlessness it cannot be captured by any sign system. ${ }^{54}$ The solution pertains in the form of presumption claiming that music does not refer to any object, it is an object itself and it can denote only when it is accompanied by words. We can try to accompany one composition with completely different and contradictory words, use the music on fundamentally different social occasions and yet we will find out that the music has not been damaged in any way. Although Sartre acknowledges that sometimes we can claim more convenience when certain music is composed to accompany a certain text, it is rather an indication and, what is more, there is an extensive repertoire of instrumental music that would have to be simply ignored.

In his argument Sartre also mentions the immanent development of musical structuring, which started by simple forms and gradually led to a higher complexity. Promoters of musical involvement would like music composers to return to obsolete music tools. This is of course inadmissible: “L'œuvre musicale n'est pas par elle-même négativité, refus des traditions, mouvement libérateur: elle set la conséquence positive de ce refus et de cette négativité." ${ }^{55}$ Music creation should grow organically from the current state of music structuring, therefore the current composition principles must be overcome, they cannot be ignored and future development cannot be dictated, because the musician's task is to find the future, after all "pour le musicien il est déjà fait" ${ }^{56}$ The future is in the past. Music involvement can be understood as a coherence of the music and the time of its origin and this is the only possible form of music involvement imaginable for Sartre. It must be included into the composition in a way that arises from musical aspects and does not rest upon factual parallels, author's intention, etc. It is a discreet presence of the epoch in all its musical manifestations, recasting the overall world perception into tones: "tout est là, donné dans les sons". ${ }^{57}$ The composer's work acts as a witness of its era, although unintentionally, and this fact cannot be changed. The only thing that could be added is perhaps awareness to changes in musical thinking and sensitivity to their value, which

\footnotetext{
53 Jean-Paul Sartre, "Preface”, in: René Leibowitz, L’Artiste et sa consience (Paris 1950), p. 9-38.

54 Cf. ibid., p. 27.

55 Ibid., p. 25.

$56 \quad$ Ibid., p. 37.

$57 \quad$ Ibid., p. 29.
} 
only time shall prove. In this way Sartre is willing to come to terms with a demand for involved music, which can be regarded as a silent manifestation of a sensitive composer and not as separate category of works, compositions, etc. The idea of involved music was not strange to Sartre, although he was privileged in the area of literature, the domain of reliable denotation.

Sartre commented on music in his autobiography and also in his novels. In a current study we, nevertheless, focuses on articles of theoretical reflexion. To this group we can add some of Sartre's later works, most likely the interview on $20^{\text {th }}$ century music. ${ }^{58}$ In this interview Sartre expresses his preferences of the $20^{\text {th }}$ century composers and he also tries to give reasons for his views. In some statements we can identify more general views on music. Sartre appears to be instructed in approaches to composition and based on listening exploration he further evaluates particular authors. Sensitivity to the composer's point of view is very typical for Sartre's aesthetically relevant opinions. ${ }^{59}$ Sartre appears to be a listener, who is very open to complicated musical structuring typical for the $20^{\text {th }}$ century, but he critically distinguishes. Although he quite appreciates Schöngerg's compositions, he regards their strict rationality as inappropriate, especially with respect to the use of traditional music forms. In Xenakis' compositions he finds purposeless, quasi-scientific rationality and he likewise evaluates Stockhausen, who combined various themes (tunes from different parts of the world) in an inconsistent symphony, whereas the composition loses its unity.

In this case Sartre appreciates the spontaneity of the expression, for example the use of human voice, which always keeps a certain meaning and sense. He detests when the voice is used as an instrument. He is able to evaluate the technical progress and his own musical experience is, to a great extent, focused on description of music structures: as a listener he observes the music flow and he likes to be surprised by the coming musical forms. He is also aware of the significant change in music of the $20^{\text {th }}$ century - partly in the shift from tones to non-tonal sounds, which in his opinion diminishes the beauty of music, and partly in loosening the temporal structure, which is acceptable, once it is not total and it does not ruin the form. The closest connection to his philosophical works comes in the form of reasoning about the expression: "Je pense que la musique est une construction, mais où chaque donnée construite représente quelque chose de l'univers humain quotidien, en particulier l'affectivité." ${ }^{60}$ So according to Sartre music is a construction, a form, and its structure refers to the everyday life, especially to affectivity. If then Sartre does not speak from the point of view of a philosophically aimed theory of art, he claims

58 Sartre commented on music on several other occasions, but only the most extensive version of his views relates to our issue. It was published in an interview: Jean-Yves Bosseur, Jean-Paul Sartre, Michel Sicard, "Sartre et la musique", Magazine littéraire, 149 (1978), June, p. 70-80.

59 As already stressed out by Eugene Kaelin, An Existentialist Aesthetic (Madison 1962), p. 57. As Sartre himself was a writer, it is quite understandable, besides Kaelin pays remarkable attention to Sartre's opinions on literature in the quoted work.

60 Jean-Yves Bosseur, Jean-Paul Sartre, Michel Sicard, "Sartre et la musique”, Magazine littéraire, 149 (1978), June, p. 77. 
that music expresses emotions and moods. To give his general statement more gravity, he emphasizes that Stravinsky musicalizes emotions ("musicalisation d'émotion" ${ }^{61}$ ). When Sartre is not interested in the technique, he can appreciate the emotional aspect of music, for example when speaking of Berg, who can express "effet dramatique, effet affectif" ${ }^{62}$

We have observed Sartre's philosophical concepts, which we have treated as musically relevant and also Sartre's opinions on music, especially with respect to its possibility to refer to non-musical reality. Throughout our reading, the role of the philosophical basis grew weaker but the support of Sartre's own experience with art grew stronger. The text did not fully comply with its original proclaimed focus, nevertheless the philosophical works we have been working with revealed the concept of Sartre's significant work L'Être et le néant (1943) and fit into Sartre's central philosophical conception. His work on emotions appears to be quite inspiring, as it builds upon the same presumptions as his work on the imaginary, but without the controversial implications of conceiving music as an image. Sartre's later opinions focused on art and also on music. They allow a certain revision of the opinions mentioned in various contexts and support some conclusions. Sartre emphasized that consciousness must, in order to refer to the world, deny the world at the same time - it must escape the world, it must not stay in it. Imagination and emotions have high affinity to art and specifically to music; they allow such nothingness, as they change our attitude towards the world.

\section{Musik in der Philosophie Jean-Paul Sartres}

\section{Zusammenfassung}

Jean-Paul Sartre (1905-1980), ein bedeutender Schriftsteller und existenzialischorientierter Phänomenologe, hatte eine enge Beziehung zur Kunst und hatte sich sehr oft über künstlerische Fragen geäußert. Seine philosophischen Erstlingswerke über die Bedeutung des emotionellen Erlebens oder über die Funktionen des Bewusstseins bei Vorstellungsgestaltung sind für Musik relevant, und zwar sowohl dank ihren direkten Hinweisen auf Musik als auch mit Ansichten, die das Hauptwerk Sein und Nichtsein (1943) antizipieren und zur zentralen philosophischen Konzeption Sartres gehören. Meine Studie behandelt das Wesen und die Verwandlungen der Anschauung Sartres auf Musik und musikalische Bedeutung, vor allem was die Fähigkeit der Musik auf außermusikalische Realität hinzuweisen betrifft. Mein Text berücksichtigt auch - neben philosophischen Entwürfen - Sartres eigene Erfahrungen mit der Kunst.

\footnotetext{
61 Ibid.

62 Ibid.
} 


\title{
Hudba ve filozofii Jeana-Paula Sartra
}

\begin{abstract}
Shrnutí
Jean-Paul Sartre (1905-1980), významný spisovatel a existencialisticky orientovaný fenomenolog, měl k umění blízko a také se $\mathrm{k}$ němu vyjadřoval. Pro hudbu jsou relevantní především jeho raná filozofická díla o významu tématu emočního prožívání či fungování vědomí při utváření představ, a to nejen přimými odkazy na hudbu, nýbrž také názory, které předjímají závažné dílo Bytí a nicota (1943) a zapadají tak do centrální Sartrovy filozofické koncepce. Studie nastiňuje povahu a proměny Sartrova nahlížení na hudbu a její význam, především $\mathrm{z}$ hlediska jejích možností odkazovat $\mathrm{k}$ mimohudební realitě, vedle filozofických konceptů přihlíží rovněž k Sartrovým vlastním zkušenostem s uměním.
\end{abstract}

\section{Key words}

Jean-Paul Sartre; imagination; inner and outer perception; nothingness; emotion; musical meaning.

\section{Klíčová slova}

Jean-Paul Sartre; představivost, vnitřní a vnější vnímání, nicota, emoce, hudební význam. 